\title{
OVERINVESTMENT IN POLISH AGRICULTURE
}

\section{Jagoda Zmyślona, $\mathrm{MSc}^{1 *}$; Arkadiusz Sadowski, $\mathrm{PhD}^{2^{* *}}$}

Faculty of Economics and Social Sciences, Poznań University of Life Sciences

${ }^{*}$ https://orcid.org/0000-0001-6386-7857

${ }^{* *}$ https://orcid.org/0000-0002-8236-1007

\begin{abstract}
The purpose of this paper was to assess the level of overinvestment in Polish farms grouped by economic size. As the volume of investments clearly continues to grow, the authors noticed the need to address that problem. Using FADN data, they developed their own method for measuring overinvestment, and identified its size and extent. Indeed, overinvestment proves to be widespread in Polish agriculture. The reasons probably include inadequate subsidies allocated under European Union aid schemes, and improper farm management practices. In the future, this could give rise to dysfunctions, ultimately resulting in farm bankruptcies.
\end{abstract}

Key words: overinvestment, Polish agriculture, FADN

JEL codes: B21, B41, D29, Q19

\section{INTRODUCTION}

The literature defines investments as the allocation of a certain amount of money (expenditure) to increase the existing value of fixed assets (Czubak, Sadowski and Wigier, 2014). Some authors take labour inputs into account in addition to financial expenditure. Also, investments are made to earn a return in the future; this means income which will compensate the investor for: the time his/her money was invested; the inflation rate; and the investment risk (Reilly and Brown, 2001). Investments involve growth in the investor's assets (Nowak, Pelichaty and Poszwa, 1999; Różański, 2006). Also, investments mean the flow of expenditure allocated to specific projects which, when implemented, do not provide immediate return and, hence, do not result in immediate consumption
(Kataria, Curtiss and Balmann, 2012). As time went by, it was found that investments could be unviable which, in the long run, means the economic operator experiences a loss. This process can also be noticed in the agriculture sector, and affects specific groups of farms to a various degree. This results in the emergence of what is referred to as overinvestment which can be defined as a condition where longterm investments are excessively high compared to the production potential (mainly land resources) and ultimately become economically unviable. Though rarely addressed in studies, this phenomenon seems to be important from both a scientific and an utilitarian perspective. Therefore, the authors carried out research in this field, using their own methodology and economic and financial performance data for farms covered by the FADN.

\footnotetext{
${ }^{1}$ Corresponding author: Wojska Polskiego 28, 60-637 Poznań, Poland, jagoda.szymczak@up.poznan.pl, +4861 8466379

${ }^{2}$ Corresponding author: Wojska Polskiego 28, 60-637 Poznań, Poland, sadowski@up.poznan.pl, +4861 8466054
} 


\section{THE PROBLEM OF OVERINVESTMENT IN AGRICULTURE}

Overinvestment in agriculture has not yet been finally defined. Bezat-Jarzębowska and Rembisz (2015) defined optimum investments as a situation where the assets-to-labour ratio of a farm grows at the same pace as labour productivity. Their conclusion was that overinvestment takes place when the assets-to-labour ratio grows while labour productivity declines. So far, the international literature has explored the problem of overinvestment in large companies in the context of state interventionism (Shen, Firth and Poon, 2016). In Poland, too, large enterprises are more concerned about overinvestment (Orłowski et al., 2010). According to other authors (Guangming and Zigi, 2013) overinvestment also affects politically-connected companies. However this were private companies with totally different specifics than agriculture. In their case, overinvestment is defined as ineffective investments which are made when companies invest in projects/solutions with a negative net value (Lei et al., 2014).

In agriculture, underinvestment and overinvestment at farm level is one of the factors which affect variability in production and therefore also have an effect on price fluctuations (Demeke and Balie, 2016). This, in turn, is caused by a deficiency or improper use of funds. In agriculture, overinvestment can be presented in a broader context of human development. Changes which have affected the global economy since the industrial revolution (mainly including the emergence of the industrial and service sectors) have resulted in a relative decrease of economic importance of agriculture measured with its contribution to GDP, for instance (Białowąs, 2016). At the same time, there was demand for labour in the new sectors which contributed to the substitution of labour with capital. This was a two-dimensional process: on the one hand, there was an outflow of labour from the agricultural sector; on the other, there was an increase in capital resources, mainly due to investments. Another consequence was the agrarian transformation, i.e. concentration of land held by an increasingly smaller number of increasingly larger farms. In this context, note that these processes took place because labour productivity was usually higher outside agriculture, and the concentration of agricultural production, together with an increase in the farms' assets-to-labour ratio, provided an opportunity for narrowing that gap. Regardless of the above, highly developed countries progressively implemented public support instruments for agriculture, including the co-financing of development investments which, in the long run, were supposed to accelerate the agrarian transformation, including the substitution of labour with capital. While this enabled the modernization of agriculture, it also contributed to overinvestment. In some cases, the allocation of public funds may (at least potentially) relax the rigidity of the microeconomic assessment of investment efficiency, resulting in excessively costly and economically unviable projects. This is especially true for the relationship between land and capital inputs. If the extent of investments in machinery or buildings is not accompanied by an increase in farm area (which, in the sectoral context, means the agrarian transformation), there is a strong risk that the increase in capital resources will not entail a simultaneous improvement in labour productivity, and thus overinvestment will take place.

Note that the above is especially true for highly developed countries. Conversely, many countries around the world struggle with the lack of capital to implement agricultural investments. Examples include Pakistan where the entire economy is based on agriculture and the considerable restrictions in access to credit have an adverse effect on agricultural development (Channa et al., 2019). All around the globe, a need has been recognized to eradicate poverty through measures which include financing for the agricultural sector, especially in countries where low incomes coexist with extensive natural resources, e.g. in Sub-Saharan Africa (FAO, 2017). Nevertheless, in some countries, increased agricultural investments continue to be ineffective.

In the group of highly developed countries, overinvestment is particularly present in the European Union. After the 1992 MacSharry reform, the level of financing for farms has been gradually decoupled from production efficiency. As a consequence, the system gave preference to farms with an appropriate area of agricultural land rather than to those at highest levels 
of production efficiency (Czyżewski, 2015). This is why Poland experiences accelerated modernization of farms (Poczta, Siemiński and Sierszchulski, 2012). Although this results in labour being substituted with capital, that process should be accompanied by improvements in labour productivity. In agriculture, this can be done either through an increase in unit productivity (mainly including increased yields) or through an extension of farm area. Subsidies for agricultural investments are important as they contribute to technical, biological, organizational and economic progress which results in enhancing the productivity and production capacity of agriculture (Czubak, 2012). As demonstrated in previous research, modernization investments are mostly implemented by large farms with great areas of agricultural land (Sadowski and Girzycka, 2011). Furthermore, the efficiency of farm investments is below the level recorded in other sectors for reasons which include the seasonality of production (Czubak, Sadowski and Wigier, 2014).

Inefficient investments often result in overinvestment, something which has not yet been defined in the context of farming. That problem will probably become apparent within a few (or ten to twenty) years. At that time, fixed assets will be fully depreciated but some credits taken out to finance the investment will remain outstanding. While overinvestment can be reasonably expected to be related to EU subsidies towards agricultural production, it is possible that it only supplements the credit. Worryingly enough, overinvestment and underinvestment in agricultural production may result in production and price fluctuations (Garrido et al., 2016).

\section{MATERIALS AND METHODS}

This paper assumes that increasing the value of farm assets through investments is a reasonable thing to do if it results in a proportional growth in labour productivity. Therefore, overinvestment is defined as a situation where:

- The increase in the value of assets results in a decline in labour productivity, which may be due to high maintenance costs of particular assets (e.g. depreciation, insurance, repairs). The above is defined as absolute overinvestment.
- Labour productivity grows at a lower rate than the value of assets. This is referred to as relative overinvestment.

The increase in the value of assets was measured using the following metric: total asset value (SE 435), including fixed assets (SE 441) and current assets (SE 465), less land value (SE 446) which, in the FADN, includes agricultural land, land improvement machinery, permanent crops, quotas and other rights attached (including purchasing costs) and forest land. Production quotas (and other rights attached) received free of charge are not appraised in the balance sheet (only the sales thereof is recorded). The rationale behind the above approach is that overinvestment is a problem which ultimately boils down to a mismatch between the farm area and the extent of investments in machinery and buildings.

Labour productivity was defined as net value added less operating and investment subsidies per FTE. Net value added was used (rather than family farm income) because of the need to eliminate the costs of external inputs (paid labour, rents, interest charged on credits) from the calculation in order to unify the economic performance figures of farms which rely on both their own and external productive inputs. The subsidies were removed from the calculation because public aid cannot be regarded as a metric of labour productivity in the economic sense. This can be assumed even if access to certain subsidies involves (at least formally) the need to perform specific actions, such as meeting the cross compliance or greening requirements in the case of payments. However, these actions refer to the production of public goods, and therefore do not have a direct impact on economic performance recorded in the market.

Investments, including overinvestment, need to be considered in the long term. Nevertheless, this paper relies on direct indices calculated independently for each subsequent year covered by the analysis. The purpose of this approach was to indicate the growth rates of both essential metrics, i.e. labour productivity and assets-to-labour ratio in each year of the study period. This allowed to indicate whether the farms grouped in different classes responded in real time to changes in both indicators and adjusted to prevailing conditions. In this context, it needs to be assumed 
that the growth rate of labour productivity largely resulted from exogenous factors (e.g. changes in prices or weather patterns). Therefore, investment decisions should depend on the estimated potential for growth in labour productivity.

This paper uses data retrieved from the European Union's Farm Accounting Data Network (FADN), a European system for accounting data collection from 28 member countries of the EU. Data is collected from commercial farms in accordance with a unified methodology. The system covers operators who make up over $90 \%$ of standard output (SO) in the country concerned. Hence, they form a representative sample of farms operating in the EU (Nowak, 2018, after Floriańczyk et al., 2016).

The problem addressed in this study was analysed based on FADN data for Polish farms grouped into six classes of economic size. Each class was assessed in terms of economic viability of investments. The following data was needed to compare that indicator: assets other than land (which is part of farm capital - C); the metric of labour inputs, defined as the annual work unit (AWU) (L); net value added (NVA) per FTE less operating and investment subsidies.

The study period was 2004-2017, with 2004 set as the base year. Overinvestment in Polish agriculture was identified in five steps:

Defining the fixed-assets-to-labour ratio $\left(F A L_{\text {ratio }}\right)$ :

$$
F A L_{\text {ratio }}=\frac{C}{L}
$$

Defining labour productivity $(L P)$ :

$$
L P=\frac{N V A}{L}
$$

Defining the increments with direct indices (2004 as the base year) for two variables: assets-to-labour ratio $\left(F A L_{\text {ratio }}\right)$ and labour productivity $(L P)$ :

$$
\begin{aligned}
& \Delta F A L_{\text {ratio }}=\frac{F A L_{\text {ratio }} \text { in the year considered }}{F A L_{\text {ratio }} \text { in the base year }} \cdot 100 \% \\
& \Delta L P=\frac{L P \text { in the year considered }}{L P \text { in the base year }} \cdot 100 \%
\end{aligned}
$$

Identifying the difference between growth in labour productivity $(L P)$ and growth in the assets-to-labour ratio $\left(F A L_{\text {ratio }}\right)$, defined as the overinvestment index $(O I)$ calculated with direct indices:

$$
\mathrm{OI}=\Delta L P-\triangle F A L_{\text {ratio }}
$$

Concluding whether the typological classes are affected by absolute or relative overinvestment or are not affected by overinvestment at all:

- absolute overinvestement: $L P<100$ and $O I<0$;

- absolute overinvestment and a negative economic results: $L P<0, F A L_{\text {ratio }}>0$ and $O I<0$;

- relative overinvestment: $L P>100$ and $O I<0$;

- optimum: $O I \approx 0$;

- underinvestment: $L P<0$ and $F A L_{\text {ratio }}<0$.

\section{RESULTS AND DISCUSSION}

With data retrieved from the FADN database, it was possible to estimate the overinvestment index (WP). It was noticed that the assumptions used in this study, as detailed in the methodology, allow to identify differences between particular classes of farms. These findings provide a basis for further research on overinvestment. Each of the classes covered by this study features a different economic potential which somehow determines the production methods but does in no event protect the operators against the phenomenon described. During the work, it was observed that each class experienced an increase in the assets-to-labour ratio over the study period (except for 2005). Hence, none of the classes were affected by underinvestment (Table 1). Other results could be observed when analysing labour productivity which tended to decrease against the base year (Table 2).

As shown by this analysis, the increase in the assets-to-labour ratio was usually higher than the increase (if any) in labour productivity. Overinvestment was noticeable already in the short run. In the long run, this can drive various dysfunctions in the agricultural market system. Overinvestment in a group of farms may lead to an increase in production costs or even to bankruptcy. This is because of the particularities of agriculture which largely depends on climate and weather conditions which have a considerable impact on prices. The next step consisted in calculating the 
Proceedings of the 2019 International Scientific Conference 'Economic Sciences for Agribusiness and Rural Economy' No 3, Warsaw, 5-7 June 2019, pp. 145-152

Table 1. Direct indices for the assets-to-labour ratio in the period 2005-2017 (2004 as the base year) (\%)

\begin{tabular}{|c|r|c|c|c|c|c|c|c|c|c|c|c|c|}
\hline Class & 2005 & 2006 & 2007 & 2008 & 2009 & 2010 & 2011 & 2012 & 2013 & 2014 & 2015 & 2016 & 2017 \\
\hline 1 & 111.3 & 116.5 & 125.1 & 139.2 & 113.6 & 126.7 & 121.8 & 105.4 & 132.7 & 136.7 & 137.2 & 137.8 & 153.2 \\
\hline 2 & 80.0 & 113.4 & 126.0 & 142.2 & 108.2 & 120.1 & 125.1 & 120.4 & 131.7 & 131.7 & 133.6 & 133.4 & 145.1 \\
\hline 3 & 66.4 & 114.7 & 127.0 & 147.9 & 116.2 & 127.1 & 133.3 & 122.6 & 128.9 & 129.0 & 129.7 & 126.9 & 138.1 \\
\hline 4 & 104.7 & 113.7 & 120.4 & 145.0 & 124.8 & 138.6 & 141.5 & 136.8 & 144.5 & 142.5 & 143.2 & 139.4 & 147.1 \\
\hline 5 & 107.4 & 111.4 & 123.6 & 136.2 & 118.9 & 125.5 & 129.1 & 145.8 & 153.9 & 152.9 & 156.7 & 149.6 & 156.5 \\
\hline 6 & 85.5 & 100.5 & 121.4 & 166.0 & 134.1 & 143.8 & 136.8 & 139.0 & 159.6 & 178.5 & 164.6 & 170.7 & 194.6 \\
\hline
\end{tabular}

Source: own compilation based on the FADN database.

Table 2. Direct indices for labour productivity in the period 2005-2017 (2004 as the base year) (\%)

\begin{tabular}{|c|r|r|r|r|r|r|r|r|r|r|r|r|r|}
\hline Class & 2005 & 2006 & 2007 & 2008 & 2009 & 2010 & 2011 & 2012 & 2013 & 2014 & \multicolumn{1}{|c|}{2015} & 2016 & 2017 \\
\hline 1 & 80.2 & 95.4 & 153.4 & 57.0 & -57.6 & 48.8 & 92.4 & 79.9 & 0.7 & -33.7 & -19.4 & -4.7 & -21.3 \\
\hline 2 & 94.0 & 111.8 & 153.0 & 82.0 & 19.7 & 84.4 & 97.1 & 87.4 & 66.5 & 34.5 & 50.8 & 28.0 & 54.8 \\
\hline 3 & 93.6 & 103.5 & 136.0 & 90.6 & 45.3 & 98.6 & 111.9 & 96.0 & 79.5 & 61.0 & 53.9 & 48.3 & 88.0 \\
\hline 4 & 92.0 & 102.3 & 128.2 & 96.3 & 61.5 & 110.3 & 118.6 & 110.2 & 95.3 & 86.0 & 72.6 & 67.8 & 113.6 \\
\hline 5 & 92.3 & 84.6 & 131.4 & 89.8 & 86.3 & 117.9 & 121.8 & 137.0 & 127.9 & 130.1 & 113.9 & 107.3 & 134.8 \\
\hline 6 & 70.7 & 68.0 & 82.0 & 72.4 & 64.7 & 82.5 & 84.7 & 93.9 & 86.4 & 86.5 & 91.1 & 85.3 & 107.1 \\
\hline
\end{tabular}

Source: own compilation based on the FADN database.

overinvestment index $(W P)$, defined as the difference between growth in labour efficiency (against 2004, the base year) and growth in the assets-to-labour ratio (Table 3).

The analysis found that the results deviated from the trend only in 2005 and 2007, when the difference went above 0 . In other cases, the result was negative which is explained by the aforementioned trend followed by the growth in the assets-to-labour ratio and in labour productivity.

The distribution of overinvestment in time in different size classes was presented in Table 4. The authors used four groups of investment ranks, as described in the methodology.

Table 3. Difference between direct indices of labour productivity and direct indices of the assets-to-labour ratio in the period 2005-2017 (\%)

\begin{tabular}{|c|r|r|r|r|r|r|r|r|r|r|r|r|c|}
\hline Class & \multicolumn{1}{c|}{2005} & \multicolumn{1}{c|}{2006} & \multicolumn{1}{c|}{2007} & \multicolumn{1}{c}{2008} & \multicolumn{1}{c}{2009} & 2010 & 2011 & 2012 & 2013 & 2014 & 2015 & 2016 & 2017 \\
\hline 1 & -31.2 & -21.2 & 28.3 & -82.2 & -171.1 & -77.9 & -29.4 & -25.5 & -132.0 & -170.4 & -156.6 & -142.5 & -174.5 \\
\hline 2 & 14.0 & -1.6 & 27.1 & -60.2 & -88.5 & -35.7 & -28.0 & -33.0 & -65.2 & -97.3 & -82.8 & -105.4 & -90.3 \\
\hline 3 & 27.2 & -11.2 & 9.0 & -57.2 & -70.9 & -28.5 & -21.4 & -26.7 & -49.4 & -68.0 & -75.8 & -78.6 & -50.0 \\
\hline 4 & -12.7 & -11.4 & 7.8 & -48.7 & -63.3 & -28.3 & -22.9 & -26.6 & -49.2 & -56.5 & -70.6 & -71.6 & -33.5 \\
\hline 5 & -15.1 & -26.8 & 7.8 & -46.3 & -32.6 & -7.6 & -7.3 & -8.8 & -26.0 & -22.8 & -42.7 & -42.3 & -21.8 \\
\hline 6 & -14.8 & -32.5 & -39.4 & -93.7 & -69.5 & -61.3 & -52.2 & -45.0 & -73.2 & -92.0 & -73.5 & -85.4 & -87.5 \\
\hline
\end{tabular}

Source: own compilation based on the FADN database. 
Proceedings of the 2019 International Scientific Conference 'Economic Sciences for Agribusiness and Rural Economy' No 3, Warsaw, 5-7 June 2019, pp. 145-152

Table 4. Viability of farm investments by economic size class

\begin{tabular}{|c|c|c|c|c|c|c|}
\hline & Class 1 & Class 2 & Class 3 & Class 4 & Class 5 & Class 6 \\
\hline Year & $\begin{array}{r}\text { from } 2000 \\
\text { to }<8000\end{array}$ & $\begin{array}{l}\text { from } 8000 \\
\text { to }<25000\end{array}$ & $\begin{array}{l}\text { from } 25000 \\
\text { to }<50000\end{array}$ & $\begin{array}{l}\text { from } 50000 \\
\text { to }<100000\end{array}$ & $\begin{array}{c}\text { from } 100000 \\
\text { to }<500000\end{array}$ & $\geq 500000$ \\
\hline 2005 & absolute & none & none & absolute & absolute & absolute \\
\hline 2006 & absolute & relative & relative & relative & absolute & absolute \\
\hline 2007 & none & none & none & none & none & absolute \\
\hline 2008 & absolute & absolute & absolute & absolute & absolute & absolute \\
\hline 2009 & $\begin{array}{c}\text { absolute }+ \\
\text { negative NVA }\end{array}$ & absolute & absolute & absolute & absolute & absolute \\
\hline 2010 & absolute & absolute & absolute & relative & relative & absolute \\
\hline 2011 & absolute & absolute & relative & relative & relative & absolute \\
\hline 2012 & absolute & absolute & absolute & relative & relative & absolute \\
\hline 2013 & absolute & absolute & absolute & absolute & relative & absolute \\
\hline 2014 & $\begin{array}{c}\text { absolute }+ \\
\text { negative NVA }\end{array}$ & absolute & absolute & absolute & relative & absolute \\
\hline 2015 & $\begin{array}{c}\text { absolute }+ \\
\text { negative NVA }\end{array}$ & absolute & absolute & absolute & relative & absolute \\
\hline 2016 & $\begin{array}{c}\text { absolute }+ \\
\text { negative NVA }\end{array}$ & absolute & absolute & absolute & relative & absolute \\
\hline 2017 & $\begin{array}{c}\text { absolute }+ \\
\text { negative NVA }\end{array}$ & absolute & absolute & relative & relative & relative \\
\hline
\end{tabular}

Source: own compilation based on calculations using data from the FADN database.

It turns out that overinvestment did not occur only in two out of thirteen years covered by this study: in 2005 in the $2^{\text {nd }}$ and $3^{\text {rd }}$ class of economic size; and in 2007 in the $1^{\text {st }}, 2^{\text {nd }}, 3^{\text {rd }}, 4^{\text {th }}$ and $5^{\text {th }}$ class of economic size. The $6^{\text {th }}$ class of economic size was affected by overinvestment throughout the study period. It was relative overinvestment only in 2017 , with absolute overinvestment found in other years. This means that in this period, the largest Polish farms reported lower levels of labour productivity than in the base year, whereas the assets-to-labour ratio was always higher than in the base year (except for 2005). Relative overinvestment, i.e. a situation where labour productivity grows against the baseline but at a slower rate than the assets-to-labour ratio, was found in economic size classes from $2^{\text {nd }}$ to $6^{\text {th }}$, with the strongest intensity being recorded in the $5^{\text {th }}$ class. In turn, the $4^{\text {th }}$ class was mostly affected by absolute overinvestment, although relative overinvestment was found in five years of the study period. The $3^{\text {rd }}$ class of economic size mostly exhibits absolute overinvestment. The same is true for the efficiency of investments made in $2^{\text {nd }}$ class. The worst situation affects the smallest farms ( $1^{\text {st }}$ class) which mostly exhibit absolute overinvestment. Furthermore, in five out of thirteen years covered by this study, this was accompanied by a negative economic result because the economic productivity of labour, in addition to falling below the baseline level, fell below the threshold level (below 0), too.

\section{CONCLUSIONS}

The analysis of this data found that $1^{\text {st }}$ class is the least viable and the most affected by overinvestment. Overinvestment accompanied by a positive economic result was mostly found in $2^{\text {nd }}, 3^{\text {rd }}$ and $6^{\text {th }}$ class. Although $4^{\text {th }}$ 
and $5^{\text {th }}$ class look better than other ones, they too are affected by overinvestment (which, however, does not involve a considerable decline in labour productivity). The index of overinvestment reflects the inefficiencies in the system and in farm management practices. These findings provide a basis for further research and economic analyses of the index of overinvestment at farm level, and for an investigation into its reasons and consequences. Although this is not a direct conclusion from this study, high levels of absolute and relative overinvestment can be related to the allocation of considerable public funds to the development of the agriculture sector. This includes not only direct support for investments under the $2^{\text {nd }}$ pillar of the CAP (main measure: "Investments" or "Young farmers") but also the use of investment funds granted as direct payments. The use of external funds for investment financing blurs the microeconomic self-assessment of different projects in terms of viability. In some cases, this leads to actions which are not fully reasonable from the economic point of view.

\section{REFERENCES}

1. Bezat-Jarzębowska, A., Rembisz, W. (2015). Wprowadzenie do analizy inwestycji, produktywności, efektywności i zmian technicznych w rolnictwie [Introduction to the analysis of investments, productivity, efficiency and technical changes in agriculture]. IERiGŻ-PIB, Warszawa.

2. Białowąs, T. (2016). Zmiany strukturalne a wzrost gospodarczy krajów Europy Środkowej [Structural changes vs. economic growth in Central European countries]. Rocznik Instytutu Europy Środkowo-Wschodniej, 14 (5), pp. 121-139.

3. Channa, A., Khan, I., Magsi, H., Channa, S.A. (2019). Farm level impacts of credit contraints on agricultural investment and income. Pakistan Journal of Agricultural Sciences, 56 (2), pp. 511-521.

4. Czubak, W. (2012). Wykorzystanie funduszy Unii Europejskiej wspierających inwestycje w gospodarstwach rolnych [European Union funds used to support farm investments]. Journal of Agribusiness and Rural Development, 3 (25), pp. 57-67

5. Czubak, W., Sadowski, A., Wigier, M. (2014). Inwestycje w rolnictwie polskim po integracji z Unią Europejską [Investments in Polish agriculture after the integration into the European Union]. Wydawnictwo Uniwersytetu Przyrodniczego w Poznaniu, Poznań.

6. Czyżewski, A. (2015). Teoriopoznawcze przesłanki rozwoju rolnictwa rodzinnego [Epistemological prerequisites for the development of family farming]. In: A. Chlebicka (ed.) Ekonomiczne mechanizmy wspierania $\mathrm{i}$ ochrony rolnictwa rodzinnego $\mathrm{w}$ Polsce $\mathrm{i}$ innych państwach Unii Europejskiej. FAPA, Warszawa, pp. 9-30.

7. Demeke, M., Balie, J. (2016). Assessment of national policies in developing countries to combat and mitigate the effects of agricultural markets' excessive price volatility. In: A. Garrido et al. (eds.) Agricultural Markets Instability. Revisiting the recent food crises. Routledge, London - New York, pp. 161-177.

8. FAO (2017). Ending poverty and hunger by investment in agriculture and rural areas. Report. Roma.

9. Garrido, A., Brümmer, B., M'Barek, R., Meuwissen, M.P.M., Morales-Opazo, C. (2016). Agricultural Markets Instability. Revisiting the recent food crises. Routledge, London - New York.

10. Kataria, K., Curtiss, J., Balmann A. (2012). Drovers of Agricultural Physical Capital Development. Theoretical Framework and Hypotheses. Factor Markets Working Paper, 18. Centre for European Policy Studies, Brussels.

11. Lei, Z., Mingchao, C., Wang, Y., Yu, J. (2014). Managerial Private Benefits and Overinvestment. Emerging Markets Finance \& Trade, 50 (3), pp. 126-161.

12. Guangming, G., Zigi, W. (2013). Political Connection, Overinvestment and Enterprise Value Empirical Evidence from Private Listed Firms in China. In: Proceedings of the 2013 International Conference on Business Computing and Global Informatization (BCGIn2010). Changsha 13-15.09.2013. IEEE Computer Society, Washington DC, pp. 653-656.

13. Nowak, A. (2018). Konkurencyjność gospodarstw mlecznych w krajach Unii Europejskiej w świetle danych FADN [Competitiveness of dairy farms in European Union countries in the light of FADN data]. Annales Universitatis Mariae Curie-Skłodowska. Lublin - Polnia. Sectio H - Oeconomia, 52 (4), pp. 49-58.

14. Nowak, E., Pelichaty, E., Poszwa, M. (1999). Rachunek opłacalności inwestycji [Investment viability appraisal]. PWE, Warszawa.

15. Orłowski, W., Pastrenak, R., Flaht, K., Szubert, D. (2010). Procesy inwestycyjne i strategie przedsiębiorstw w czasach kryzysu [Investment processes and corporate strategies in crisis periods]. PARP, Warszawa. 
16. Poczta, W., Siemiński, P., Sierszchulski, J. (2012). Przestrzenne zróżnicowanie aktywności rolników w pozyskiwaniu środków unijnych na rozwój gospodarstw rolnych w Wielkopolsce na przykładzie działania „Modernizacja gospodarstw rolnych” [Spatial Diversity of Activities of Farmers in Obtaining EU Funds for the Development of Farms in the Wielkopolska Voivodeship on the Example of the Measure „Modernisation of Agricultural Holdings”]. Journal of Agribusiness and Rural Development, 3 (25), pp. 207-223.

17. Reilly, F.K., Brown, K.C. (2001). Analiza inwestycji i zarządzanie portfelem [Investment analysis and portfolio management]. PWE, Warszawa.
18. Różański, J. (2006). Inwestycje rzeczowe i kapitałowe [Investment in tangible assets and equity investments]. Difin, Warszawa.

19. Sadowski, A., Girzycka, W. (2011). Rolnicze inwestycje modernizacyjne i dostosowujące do standardów UE, finansowane ze środków unijnych [Agricultural Investments of Modernization and Meeting EU Standards, Financed by European Union Founds]. Zeszyty Naukowe SGGW. Polityki Europejskie, Finanse i Marketing, 6 (55), pp. 122-128.

20. Shen, J. Firth, M., Poon, W.P.H. (2016). Credit expansion, corporate finance and overinvestment: recent evidence from China. Pacific-Basin Finance Journal, 39, pp. 16-27. 